\title{
Cold blood cardioplegia versus cold crystalloid cardioplegia: A prospective randomized study of 1440 patients undergoing coronary artery bypass grafting
}

\author{
Eivind Øvrum, MD, PhD \\ Geir Tangen, MD \\ Stein Tølløfsrud, MD, PhD \\ Rolf Øystese, CCP \\ Mari Anne L. Ringdal, CCP \\ Reidar Istad, CCP
}

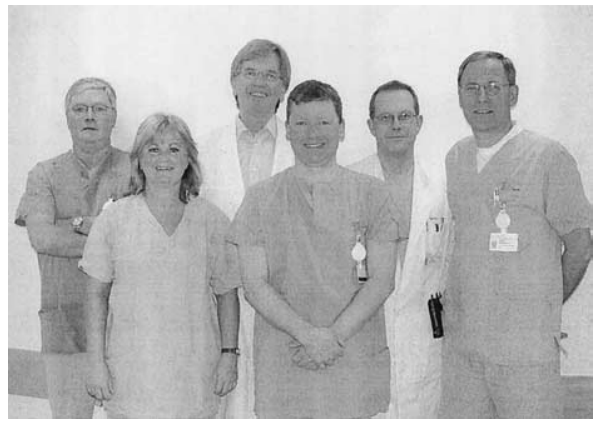

Left to right: Istad, Ringdal, Øvrum, Øystese, Tangen, Tølløfsrud
From the Oslo Heart Center, Oslo, Norway. Received for publication Feb 5, 2004; revisions requested March 9, 2004; accepted for publication March 25, 2004

Address for reprints: Eivind $\emptyset_{\mathrm{v} r u m}, \mathrm{MD}$, $\mathrm{PhD}$, Oslo Heart Center, Box 2684, St Hanshaugen, 0131 Oslo, Norway (E-mail: eivind.ovrum@hjertesenteret.no).

J Thorac Cardiovasc Surg 2004;128:860-5

$0022-5223 / \$ 30.00$

Copyright (C) 2004 by The American Association for Thoracic Surgery

doi:10.1016/j.jtcvs.2004.03.032
Objectives: A large number of experimental studies have indicated that blood cardioplegia might be superior to crystalloid cardioplegia for myocardial protection during ischemic arrest. However, no prospectively randomized studies of large patient series have been undertaken to prove potential differences in clinical course.

Methods: Over a 52-month period, all patients undergoing on-pump coronary artery bypass operated on by 2 surgeons were prospectively randomized to receive either cold crystalloid cardioplegia (group C) or cold blood cardioplegia (group B) during aortic crossclamping.

Results: Altogether, 1440 patients aged 37 to 89 years (median, 66 years) entered the study (group $\mathrm{C}, \mathrm{n}=719$; group $\mathrm{B}, \mathrm{n}=721$ ). The groups were comparable in all major demographic, preoperative, and operative variables. The clinical course turned out to be nearly identical for both groups. No statistically significant differences were seen concerning spontaneous sinus rhythm after aortic declamping, use of inotropic drugs or intra-aortic balloon pumping, postoperative ventilatory support, bleeding and rate of allogeneic blood transfusions, perioperative myocardial infarction, episodes of atrial fibrillation, stroke or minor neurologic dysfunction, renal function, infections, physical rehabilitation, or mortality. Also, in subgroups of patients at higher operative risk (female sex, age $>70$ years, unstable angina, diabetes, emergency operation, ejection fraction $<0.50$, crossclamping time $>50$ minutes, and EuroSCORE $>4$ ), no statistically significant differences could be demonstrated between the groups.

Conclusions: There were no significant differences whether myocardial protection was performed with cold blood cardioplegia or cold crystalloid cardioplegia during aortic crossclamping in patients undergoing coronary artery bypass grafting. The extra costs related to blood cardioplegia might be saved.

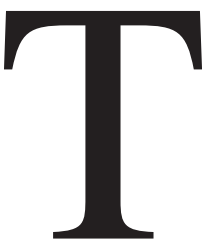

he optimal method for protection of the myocardium during ischemic arrest has been debated since the very beginning of modern cardiac surgery. A large variety of techniques have been advocated, and obviously few institutions have identical protocols for myocardial protection. This makes true differences in clinical results very difficult to evaluate. However, 2 main techniques have gained widespread acceptance: cardiac arrest induced and maintained with potassium added to a blood-based solution or a crystalloid-based solution. Several experimental studies favor the use of blood cardioplegia when investigating release of cardiac enzymes, 
TABLE 1. Demographic variables and operative risk factors in patients receiving crystalloid cardioplegia (group C) and blood cardioplegia (group B)

\begin{tabular}{|c|c|c|c|}
\hline Variables & Group C (n = 719) & Group B (n = 721) & $P$ value \\
\hline Age (y) & $65.0 \pm 9.2$ & $64.9 \pm 9.8$ & .95 \\
\hline Age $>70$ y ( $\%$ of patients) & 35.0 & 35.8 & .81 \\
\hline Female sex $(\%)$ & 20.0 & 20.4 & .86 \\
\hline Weight $(\mathrm{kg})$ & $82.2 \pm 14.2$ & $81.5 \pm 14.1$ & .33 \\
\hline Diabetes ( $\%$ of patients) & 13.9 & 16.8 & .34 \\
\hline Emergency operation ( $\%$ of patients) & 19.3 & 19.1 & .94 \\
\hline Redo operation ( $\%$ of patients) & 2.4 & 2.5 & .70 \\
\hline Ejection fraction & $0.68 \pm 0.14$ & $0.68 \pm 0.14$ & .76 \\
\hline Ejection fraction $<0.5$ ( $\%$ of patients) & 13.4 & 13.9 & .88 \\
\hline Previous myocardial infarction ( $\%$ of patients) & 51.0 & 50.5 & .85 \\
\hline EuroSCORE $4-12 ;$ mean, 5.6 ( $\%$ of patients) & 41.0 & 44.2 & .24 \\
\hline
\end{tabular}

metabolic response, and other laboratory test results. ${ }^{1}$ In clinical studies focusing on patient outcome variables, the effects of blood cardioplegia have most often been matched with those in historical control groups, with indications of being superior to the effects of crystalloid cardioplegia. ${ }^{2,3}$ However, no larger prospectively randomized studies have thus far been reported.

The present investigation was designed and performed in a standardized fashion to minimize the inevitable problems of methodologic bias when performing clinical studies. The patient material included only patients undergoing coronary artery bypass grafting (CABG) with no additional operations who were operated on by 2 senior surgeons. The practices of surgical techniques, such as aortic crossclamping, use of the internal thoracic artery, body temperature, and mode of administration of cardioplegia, were identical throughout the study period. The postoperative management was standardized in all aspects, including a nonpharmacologic blood conservation strategy and a fast-tracking recovery protocol. The same staff of anesthetists and perfusionists treated all patients during the entire study. Thus the method of prospective randomization of all patients left the only difference between the 2 groups to be the composition of the cardioplegic solution.

The major aim of the study was to investigate all relevant clinical outcome variables in a large and homogenous patient population. Except for routine monitoring of enzymes indicating perioperative myocardial infarction, no other biochemical markers to evaluate myocardial function were studied.

\section{Material and Methods \\ Patients}

From January 2000 through April 2003, 1440 consecutive patients undergoing on-pump CABG operated on by one of 2 surgeons (EØ, GT) entered the study. Four patients operated on without aortic crossclamping and one patient having CABG without cardiopulmonary bypass (CPB) were excluded. No other patients undergoing coronary bypass were excluded for any reasons during the period under investigation. Informed consent was not obtained from the patients because both methods of myocardial protection are universally accepted.

The majority of the patients underwent surgical intervention on an elective basis. About 20\% were emergency cases, identified as patients operated on within 1 week after onset of symptoms, after angiography, or both. Thirty-five $(2.4 \%)$ patients had their second revascularization, with equal distribution across the groups (Table 1). Diabetic patients were defined as those using insulin $(6.9 \%)$ or receiving oral medication $(8.5 \%)$. The patient material is somewhat selected because of the close collaboration with a neighboring university department, in which care is provided to patients with severe renal dysfunction, patients with ventricular aneurysms, and patients in need of combined carotid and coronary operations and acute operations after failed angioplasties. Table 1 outlines the patient characteristics of both groups.

\section{Anesthesia and Operation}

The anesthesia protocol was designed to permit early postoperative extubation. After induction with diazepam $(0.1-0.2 \mathrm{mg} / \mathrm{kg})$, fentanyl (3- $5 \mu \mathrm{g} / \mathrm{kg})$, thiopenthal $(0.5-2.0 \mathrm{mg} / \mathrm{kg})$, and pancuronium bromide $(0.1 \mathrm{mg} / \mathrm{kg})$, anesthesia was maintained with isoflurane ( $0.5 \%$ to $1.0 \%$ inspired). During CPB, propofol (2-4 $\mathrm{mg} \cdot \mathrm{kg}^{-1}$. $\left.\mathrm{h}^{-1}\right)$ was given in addition to fentanyl $(1-2 \mu \mathrm{g} / \mathrm{kg})$.

The extracorporeal circulation was performed with a Stöckert roller pump with a pulsatile flow control (PFC III; Stöckert Instrumente $\mathrm{GmbH}$, Munich, Germany). Because of the routine practice of our institution, all CPB was undertaken with heparin-coated systems. The Carmeda Bio-Active Surface system (Medtronic Inc, Minneapolis, Minn) and the Duraflo II equipment (Baxter Healthcare Corp, Bentley Laboratories Division, Irvine, Calif) were used in equal numbers in both groups. The circuits were primed with $2000 \mathrm{~mL}$ of Ringer acetate. Systemic heparinization was reduced (activated clotting time [ACT] $>250$ seconds) in all first-time operations, and a full heparin dose (ACT $>480$ seconds) was administered in all redo cases. The standard sizes of the aortic and the 2 -stage venous cannulas were $22 \mathrm{~F}$ and $48 \mathrm{~F}$, respectively. Mild hypothermia (blood temperature $32^{\circ} \mathrm{C}$ ) was instituted immediately after the start of bypass. A cardiotomy suction line was available and frequently used during $\mathrm{CPB}$. 
TABLE 2. Operative variables in patients receiving crystalloid cardioplegia (group C) and blood cardioplegia (group B)

\begin{tabular}{lccc}
\hline Variables & $\begin{array}{c}\text { Group C } \\
\text { (n= 719) }\end{array}$ & $\begin{array}{c}\text { Group B } \\
(\mathbf{n}=\mathbf{7 2 1})\end{array}$ & $\boldsymbol{P}$ value \\
\hline $\begin{array}{l}\text { Amount of cardioplegic } \\
\text { solution given (mL) }\end{array}$ & $810 \pm 173$ & $817 \pm 287$ & .08 \\
$\begin{array}{l}\text { At least one internal thoracic } \\
\text { artery anastomosis (\% of }\end{array}$ & 99.9 & 99.4 & .86 \\
$\quad$ patients) & & & \\
$\begin{array}{l}\text { No. of distal anastomoses } \\
\text { Ischemic time (min) }\end{array}$ & $4.5 \pm 1.2$ & $4.6 \pm 1.1$ & .02 \\
$\begin{array}{l}\text { Extracorporeal time (min) } \\
\begin{array}{l}\text { Spontaneous sinus rhythm } \\
\text { after declamping (\% of }\end{array}\end{array}$ & $52.2 \pm 11.6$ & $53.5 \pm 11.6$ & .18 \\
$\quad$ patients) & 85.3 & 81.8 & .13 \\
& & & \\
\hline
\end{tabular}

The aorta was crossclamped during performance of the distal anastomoses. At least one internal thoracic artery anastomosis was constructed in almost all patients (Table 2), and this was supplemented with saphenous vein grafts or the radial artery in some cases. The proximal anastomoses were performed during partial occlusion of the ascending aorta while the patient was being rewarmed.

\section{Myocardial Protection}

Group B. A Duraflo II coated (D II HE-30 Gold; (Baxter Healthcare Corp, Bentley Laboratories Division) blood cardioplegia set was used in all patients. The cardioplegia set was mounted on a double-pump system with a slave function combined with a heater-cooler unit. At reduced ACT ( $>250$ seconds), the cardioplegia system was circulated at all times until the end of CPB.

The blood cardioplegia was mixed at a ratio of 1:4 and delivered antegradely into the aorta. A volume of 500 to 800 $\mathrm{mL}$ was given initially until cardiac arrest, and thereafter, 100 to $300 \mathrm{~mL}$ was given if return of electrical activity was seen. The temperature ranged between $6^{\circ} \mathrm{C}$ and $10^{\circ} \mathrm{C}$. The concentrations of the components were as follows: potassium chloride, $20 \mathrm{mmol} / \mathrm{L}$; magnesium chloride, $17 \mathrm{mmol} / \mathrm{L}$; calcium chloride, $2 \mathrm{mmol} / \mathrm{L}$; procaine hydrochloride, $1 \mathrm{mmol} / \mathrm{L}$; bicarbonate, 25 $\mathrm{mmol} / \mathrm{L}$; and $\mathrm{Ph}, 7.35$ to 7.45 . Compared with crystalloid cardioplegia, the lines for blood cardioplegia represented an extra cost of about $\$ 130$ US.

Group $C$. The cardioplegic solution was mixed in Ringer acetate and stored at $4^{\circ} \mathrm{C}$. The temperature of the infusate was about $4^{\circ} \mathrm{C}$ to $8^{\circ} \mathrm{C}$. The mode of administration and concentration of electrolytes and procaine was identical in the 2 groups.

The blood conservation protocol of the institution, previously described in detail, ${ }^{4}$ was applied to all patients. Normovolemic anemia was accepted to a hematocrit level of 0.25 postoperatively; a level less than this was considered an indication for allogeneic red blood cell transfusion. The hemoglobin concentration and platelet count were determined preoperatively, at 3 hours and 18 hours postoperatively, and at discharge on the fifth to seventh day.

\section{Postoperative Arrhythmias}

After routine electrocardiogram (ECG) registration during the day of the operation, all patients were monitored with continuous telemetry for 48 hours. In cases of arrhythmias, telemetry was prolonged or reinstituted. All patients having one or more episodes of arrhythmias were prospectively registered. Preoperative medication ( $\beta$-blockers, $\mathrm{Ca}^{++}$-channel blockers, and digitalis) were continued from the first day after the operation. In those patients not receiving $\beta$-blockers preoperatively, such treatment was instituted at the first postoperative day.

\section{Diagnosis of Perioperative Myocardial Infarction}

All patients had serial 12-lead ECG examination and enzyme analysis preoperatively and at 6,24, and 48 hours postoperatively, as well as at discharge from the hospital. The interpretations of the ECGs were prospectively done by experienced consultant cardiologists who made their diagnosis blindly related to the study. Development of new Q-waves of more than 0.03 seconds, in combination with a significant increase of aspartate aminotransferase and creatine kinase MB exceeding 2.5 as the upper normal level, was defined as definite myocardial necrosis.

\section{Rehabilitation}

After the operation, the patients were extubated as soon as possible after cardiorespiratory stabilization. For practical reasons, the patients stayed in the intensive care unit until the next morning. Most often, the mediastinal drains and the venous and arterial lines were then removed, and the patients were taken out of bed for light physical training. From the third postoperative day, the patients were usually allowed to move freely outside the hospital. A detailed registration of the steps of physical recovery was included in the patient data form.

\section{Statistical Analysis}

Comparison of the 2 groups was done by using the Mann-Whitney $U$ test for continuous variables. Discrete variables were treated by means of contingency tables, with the Yates correction and the Fisher test performed when one of the expected cell values was less than 5 . The data are presented as means \pm SDs. All data were recorded prospectively and stored in a database.

\section{Results}

The demographic data are listed in Table 1, and there were no statistically significant differences between the groups. There were slightly statistically significant differences in the number of distal anastomoses and the time for extracorporeal circulation (Table 2). However, from a clinical point of view, the disparities were negligible. The total amount of cardioplegic solution was similar in both groups. Although group $\mathrm{C}$ received about $600 \mathrm{~mL}$ more clear fluid in the cardioplegic solution, the fluid balance at arrival in the intensive care unit was not accordingly different (Table 2), indicating that the anesthetist, perfusionist, or both, because of common indications, added more fluid to group B during the operation. Sinus rhythm returned spontaneously after declamping of the aorta at equal proportion in the 2 groups. 
TABLE 3. Postoperative variables in patients receiving crystalloid cardioplegia (group C) and blood cardioplegia (group B)

\begin{tabular}{|c|c|c|c|}
\hline Variables & $\begin{array}{c}\text { Group C } \\
(\mathrm{n}=719)\end{array}$ & $\begin{array}{c}\text { Group B } \\
(\mathrm{n}=721)\end{array}$ & $P$ value \\
\hline Mediastinal drainage $18 \mathrm{~h}$ postoperatively (mL) & $665 \pm 296$ & $631 \pm 258$ & .008 \\
\hline Resternotomy for bleeding ( $\%$ of patients) & 2.4 & 1.7 & .34 \\
\hline Red cells ( \pm plasma) transfusions ( $\%$ of patients) & 5.0 & 6.9 & .13 \\
\hline Hemoglobin concentration preoperatively $(\mathrm{g} / \mathrm{L})$ & $141 \pm 13$ & $141 \pm 13$ & .99 \\
\hline Hemoglobin concentration at discharge $(\mathrm{g} / \mathrm{L})$ & $118 \pm 14$ & $118 \pm 13$ & .94 \\
\hline Mediastinitis (\% of patients) & 0.4 & 0.4 & .68 \\
\hline Moving outside bed on postoperative day 1 ( $\%$ of patients) & 98.9 & 99.2 & .77 \\
\hline Walking stairs-outdoors before postoperative day 3 ( $\%$ of patients) & 62.0 & 59.6 & .43 \\
\hline
\end{tabular}

The postoperative mediastinal drainage was somewhat reduced in group B (Table 3). Although the difference was statistically significant, the clinical effect was hardly noticeable. The need for transfusion of allogeneic blood products was low in both groups, without intergroup differences.

The additional clinical outcome variables are shown in Table 4. The patients were extubated early in both groups. There were no differences in the rate of perioperative myocardial infarction, use of inotropic drugs, arrhythmias, incidence of neurologic complications, infections, or progress of physical rehabilitation. Thirty-day mortality was $0.4 \%$ (3 patients) in group $\mathrm{C}$ and $0.6 \%$ (4 patients) in group $\mathrm{F}$ ( $P=$ $.071)$.

The following subgroups of higher-risk patients were tested for all preoperative and postoperative variables, which are included in Tables 2 to 4: age greater than 70 years $(\mathrm{n}=445)$; unstable angina-urgent operation $(\mathrm{n}=$ $231)$; diabetes $(\mathrm{n}=193)$; ejection fraction less than $0.5(\mathrm{n}$ $=166)$; female sex $(\mathrm{n}=149)$; redo operation $(\mathrm{n}=35)$; EuroSCORE greater than 4 (mean, 5.6; $\mathrm{n}=614$ ); and aortic crossclamp time of greater than 50 minutes (mean, 56.1 minutes; $\mathrm{n}=91$ ).

The number of patients was similar across the groups. There were no statistically significant differences between the patients in group $\mathrm{C}$ or the patients in group $\mathrm{B}$.

In particular, the analysis of patients at higher operative risk (EuroSCORE, 4-12) did not show any intergroup differences (Table 5).

\section{Discussion}

There is a magnitude of technical modifications for protecting the heart during ischemic arrest, such as different temperature (cold, tepid, warm), ${ }^{5,6}$ different administration (antegrade, retrograde, and combinations of both), ${ }^{7,8}$ additive substrates, or drugs. ${ }^{3,9-12}$ The large amount of laboratory studies, most of them indicating the benefit of blood cardioplegia, ${ }^{1,3}$ do not really help the clinician to evaluate the effects on the most relevant patient outcome variables, particularly because of the lack of larger prospectively randomized patient studies.
The definite aim of the present study was to include a substantial number of patients to obtain sufficient statistical power for evaluation of the most relevant factors affecting the postoperative course. The patient selection and management was performed in a standardized fashion to overcome the methodologic problems related to all clinical trials (eg, various staff, different surgical approaches, variations of anesthesia protocols over time, and mix of patients). This was possible because our department is run mainly by only 2 surgeons, and a single anesthetist supervises the intraoperative and postoperative treatment of most patients. Therefore the practices of surgical methods and techniques for anesthesia and perfusion remained similar throughout the study period.

Being enthusiastic toward blood cardioplegia for many years, we were somewhat disappointed after realizing that no overall clinical benefits were seen when comparing blood cardioplegia and crystalloid cardioplegia. Even more, no beneficial effects could be shown in groups of patients at higher operative risk, such as those with unstable angina, redo operations, lower ejection fraction, female sex, diabetes, or older age. In fact, a substantial number of patients with a higher preoperative risk score were available for analysis, but no statistically significant differences were demonstrated (Table 5). A general limitation of the study might be the relatively short mean ischemic time and CPB time. However, analysis of the subgroup of patients having a prolonged aortic crossclamping time did not reveal any significant differences.

Our results are similar to those of other randomized series, ${ }^{13-15}$ in which no difference between cold blood and cold crystalloid cardioplegia could be seen, whereas others suggested improved myocardial protection with blood cardioplegia. 1,16,17 The results remain inconclusive and confusing because of the limited number of patients in all the reported studies. No randomized controlled clinical studies exceeding 140 adult patients could be traced in the literature.

Conduction disturbances have been reported with the use of blood cardioplegia. ${ }^{18}$ Others ${ }^{19}$ have demonstrated a 
TABLE 4. Cardiopulmonary variables in patients receiving crystalloid cardioplegia (group C) and blood cardioplegia (group B)

\begin{tabular}{|c|c|c|c|}
\hline Variables & $\begin{array}{c}\text { Group C } \\
(n=719)\end{array}$ & $\begin{array}{c}\text { Group B } \\
(\mathrm{n}=721)\end{array}$ & $P$ value \\
\hline Ventilatory support postoperatively (h) & $1.8 \pm 1.3$ & $1.9 \pm 1.1$ & .26 \\
\hline Perioperative myocardial infarction ( $\%$ of patients) & 0.4 & 0.9 & .48 \\
\hline Inotropic medication, $>30$ minutes ( $\%$ of patients) & 0.4 & 1.4 & .05 \\
\hline Intra-aortic balloon pumping ( $\%$ of patients) & 0 & 0.2 & .37 \\
\hline Postoperative AF; preoperative AF excluded ( $\%$ of patients) & 28.5 & 30.3 & .49 \\
\hline Stroke ( $\%$ of patients) & 1.1 & 0.7 & .46 \\
\hline Minor neurologic events ( $\%$ of patients) & 1.2 & 0.7 & .30 \\
\hline Hospital mortality, $30 \mathrm{~d}$ (\% of patients) & 0.4 & 0.6 & .71 \\
\hline
\end{tabular}

$A F$, Atrial fibrillation.

TABLE 5. Postoperative outcome variables in patients at higher operative risk (EuroSCORE 4-12) receiving crystalloid cardioplegia (group C) and blood cardioplegia (group B)

\begin{tabular}{|c|c|c|c|}
\hline Variables & $\begin{array}{c}\text { Group C } \\
(\mathrm{n}=295)\end{array}$ & $\begin{array}{c}\text { Group B } \\
(n=319)\end{array}$ & $P$ value \\
\hline EuroSCORE & $5.6 \pm 1.7$ & $5.5 \pm 1.6$ & .81 \\
\hline Ventilatory support postoperatively (h) & $2.1 \pm 1.7$ & $2.1 \pm 1.1$ & .29 \\
\hline Perioperative myocardial infarction ( $\%$ of patients) & 0.3 & 1.3 & .21 \\
\hline Inotropic medication, $>30$ min (\% of patients) & 0.7 & 2.5 & .07 \\
\hline Intra-aortic balloon pumping ( $\%$ of patients) & 0 & 0.3 & .35 \\
\hline Postoperative AF; preoperative AF excluded ( $\%$ of patients) & 36.5 & 39.9 & .68 \\
\hline Stroke ( $\%$ of patients) & 2.7 & 1.7 & .41 \\
\hline Minor neurologic events ( $\%$ of patients) & 2.7 & 0.9 & .15 \\
\hline Hospital mortality, $30 \mathrm{~d}$ ( $\%$ of patients) & 0.7 & 1.3 & .65 \\
\hline
\end{tabular}

$A F$, Atrial fibrillation.

higher incidence of spontaneous resumption of sinus rhythm after blood cardioplegia compared with that after crystalloid cardioplegia. In the present study no statistical differences concerning conduction disturbances were seen. The relatively high rate of spontaneous return of sinus rhythm in both groups might be related to the addition of procaine to the cardioplegic solution. ${ }^{20}$

According to the routine practice of our institution, heparin-coated extracorporeal circuits were used in every patient. We and others ${ }^{21,22}$ have previously demonstrated the beneficial effects of heparin-coated circuits on the total body inflammatory response, the incidence of postoperative atrial fibrillation, and reduced postoperative bleeding. ${ }^{23}$ These clinical environments might have influenced the overall clinical results, particularly considering the low morbidity rate and the 30-day mortality rate. However, for the present investigation, the technical modification of the extracorporeal circulation did not interfere with the results of the study as such because the techniques of CPB were identical in both groups.

In summary, in this prospectively randomized study including a substantial number of patients undergoing $\mathrm{CABG}$, there were no significant differences in any major clinical end points whether the myocardium was protected with cold blood cardioplegia or cold crystalloid cardioplegia during aortic crossclamping. The extra costs related to mechanical pumps and disposable equipment might be saved.

\section{References}

1. Barner HB. Blood cardioplegia: a review and comparison with crystalloid cardioplegia. Ann Thorac Surg. 1991;52:1354-67.

2. Loop FD, Higgins TL, Panda R, Pearce G, Estafanous FG. Myocardial protection during cardiac operations. J Thorac Cardiovasc Surg. 1992; 104:608-18.

3. Cohen G, Borger MA, Weisel RD, Rao V. Intraoperative myocardial protection: current trends and future perspective. Ann Thorac Surg. 1999;68:1995-2001.

4. Øvrum E, Ăm Holen E, Tangen G. Consistent non-pharmacologic blood conservation in primary and reoperative coronary artery bypass grafting. Eur J Cardiothorac Surg. 1995;9:30-5.

5. Fiore AC, Swartz MT, Nevett R, Vieth PJ, Magrath RA, Sherrick A, et al. Intermittent antegrade tepid versus cold blood cardioplegia in elective myocardial revascularization. Ann Thorac Surg. 1998;65: 1559-65.

6. Mallidi HR, Sever J, Tamariz M, Singh S, Hanayama N, Christakis GT, et al. The short-term and long-term effects of warm or tepid cardioplegia. J Thorac Cardiovasc Surg. 2003;125:711-20.

7. Buckberg GD, Beyersdorf F, Allen BS, Robertson JM. Integrated myocardial management: background and initial application. J Card Surg. 1995; 10:68-89.

8. Chocron S, Alwan K, Toubin G, Clement F, Kaili D, Taberlet C, et al. Crystalloid cardioplegia route of delivery and cardiac troponin release. Ann Thorac Surg. 1996;62:481-5. 
9. Kjellman U, Bjork K, Ekroth R, Karlsson H, Jagenburg R, Nilsson F. Alfa-ketoglutarate for myocardial protection in heart surgery. Lancet. 1995;345:552-3.

10. Hynninen M, Borger MA, Rao V, Weisel RD, Christakis GT, Carroll Cheng DC. The effect of insulin cardioplegia on atrial fibrillation after high risk coronary bypass surgery: a double-blinded, randomized controlled trial. Anesth Analg. 2001;92:810-6.

11. Carrier M, Pellerin M, Perrault LP, Bouchgard D, Page P, Searle N, et al. Cardioplegic arrest with L-arginine improves myocardial protection: results of a prospective randomized clinical trial. Ann Thorac Surg. 2002;73:837-41.

12. Chambers DJ, Haire K, Morley N, Fairbanks L, Strumia E, Young CP, et al. St. Thomas' Hospital cardioplegia: enhanced protection with exogenous creatine phosphate. Ann Thorac Surg. 1996;61:67-75.

13. Hendrikx M, Jiang H, Guterman H, Toelsie J, Renard D, Briers A, et al. Release of cardiac troponin I in antegrade crystalloid versus blood cardioplegia. J Thorac Cardiovasc Surg. 1999;118:452-9.

14. Young JN, Choy IO, Silva NK, Obayashi DY, Barkan HE. Antegrade cold blood cardioplegia is not demonstrably advantageous over cold crystalloid cardioplegia in surgery for congenital heart disease. J Thorac Cardiovasc Surg. 1997;114:1002-9.

15. Caputo M, Dihmis W, Birdi I, Reeves B, Suleiman MS, Angelini GD, et al. Cardiac troponin $\mathrm{T}$ and troponin I release during coronary artery surgery using cold crystalloid and cold blood cardioplegia. Eur J Cardiothorac Surg. 1997;12:254-60.

16. Fremes SE, Christakis GT, Weisel RD, Mickle DA, Madonik MM,
Ivanov J, et al. A clinical trial of blood and crystalloid cardioplegia. J Thorac Cardiovasc Surg. 1984;88:726-41.

17. Ibrahim MF, Venn GE, Young CP, Chambers DJ. A clinical comparative study between crystalloid and blood-based St. Thomas' hospital cardioplegic solution. Eur J Cardiothorac Surg. 1999;15:75-83.

18. Gundry SR, Sequeira A, Coughlin TR, McLaughlin JS. Postoperative conduction disturbances: a comparison of blood and crystalloid cardioplegia. Ann Thorac Surg. 1989;47:384-90.

19. Rinne T, Pehkonen E, Kaukinen S, Tarrka M. Comparison of cardioprotection with crystalloid and blood cardioplegia in CABG patients. J Cardiothorac Vasc Anesth. 1993;7:679-83.

20. Sellevold OF, Berg EM, Levang OW. Procaine is effective for minimizing postischemic ventricular fibrillation in cardiac surgery. Anesth Analg. 1995;81:932-8.

21. Øvrum E, Mollnes TE, Fosse E, Holen EA, Tangen G, Ringdal MA, et al. High and low heparin dose with heparin-coated cardiopulmonary bypass: activation of complement and granulocytes. Ann Thorac Surg. 1995;60:1755-61

22. Fosse E, Moen O, Johnson E, Semb G, Brockmeier V, Mollnes TE, et al. Reduced complement and granulocyte activation with heparin coated cardiopulmonary bypass. Ann Thorac Surg. 1994;58:472-7.

23. Aldea G, O'Gara P, Shapira OM, Treanor P, Osman A, Patalis E, et al. Effect of anticoagulation protocol on outcome in patients undergoing CABG with heparin-bonded cardiopulmonary bypass circuits. Ann Thorac Surg. 1998;65:425-33.

Access to The Journal of Thoracic and Cardiovascular Surgery Online is reserved for print subscribers!

Full-text access to The Journal of Thoracic and Cardiovascular Surgery Online is available for all print subscribers. To activate your individual online subscription, please visit The Journal of Thoracic and Cardiovascular Surgery Online, point your browser to http://www.mosby.com/itcvs, follow the prompts to activate your online access, and follow the instructions. To activate your account, you will need your subscriber account number, which you can find on your mailing label (note: the number of digits in your subscriber account number varies from 6 to 10). See the example below in which the subscriber account number has been circled:

\section{Sample mailing label}

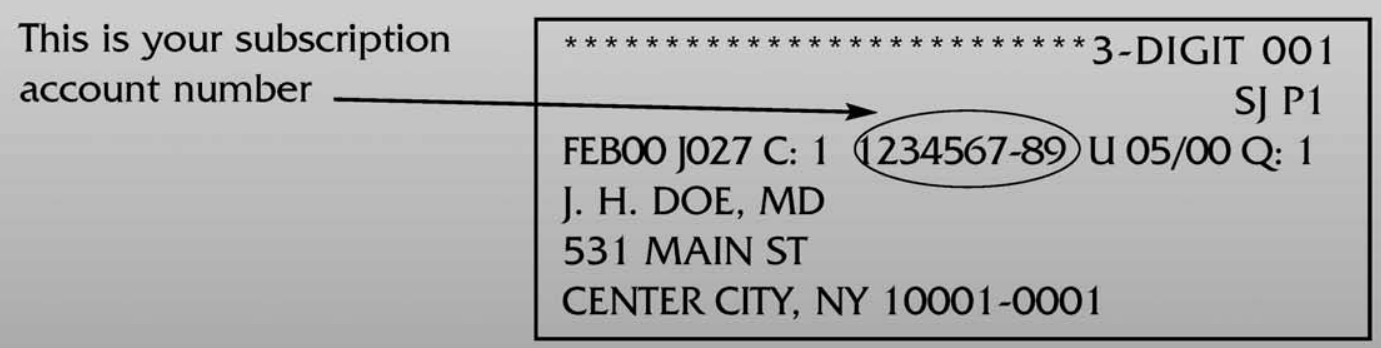

Personal subscriptions to The Journal of Thoracic and Cardiovascular Surgery Online are for individual use only and may not be transferred. Use of The Journal of Thoracic and Cardiovascular Surgery Online is subject to agreement to the terms and conditions as indicated online. 